\title{
Analysis of the Effect of Local Tax Revenues, Regional Retributions, and Profit Sharing Funds on Capital Expenditures in Regencies / Cities of North Sulawesi Province of Indonesia
}

\author{
Coraima Dilapanga, Sihwahjoeni, Achmad Firdiansjah \\ University of Merdeka Malang \\ Indonesia
}

\begin{abstract}
This study aims to analyze the effect of local tax revenues, regional levies and profit sharing funds simultaneously on capital expenditures, analyze the effect of local tax revenues on capital spending, analyze the effect of local levies on capital expenditures and analyze the effect of profit sharing funds on capital spending in the district. / City of North Sulawesi Province. The sample in this study was as much10 districts / cities in North Sulawesi Province. The analysis technique uses multiple regression analysis. The results of the analysis show that local taxes, local levies and profit sharing funds simultaneously affect capital expenditures, which means that the higher local tax revenues, supported by high local fees and profit sharing funds, can increase capital spending. Local taxes have an effect on capital expenditures in districts / cities of North Sulawesi Province, which means that high regional taxes are a consideration for local governments in using the revenues received so that it has an impact on increasing capital spending in districts / cities of North Sulawesi Province. Regional levies do not have a significant effect on capital spending in districts / cities of North Sulawesi Province, which means that the high and low level of local fees does not have an impact on the level of capital expenditure in districts / cities of North Sulawesi Province. Profit sharing funds have no effect on capital expenditure, which means that the high and low level of profit sharing funds does not have an impact on the level of capital expenditure in districts / cities of North Sulawesi Province.
\end{abstract}

Keywords: Local Taxes, Regional Levies, Profit Sharing Funds, Capital Expenditures.

\section{INTRODUCTION}

Regional Government in administering governance prepares a budget which is then used as a guide in carrying out various activities. Government budget is a type of plan that describes a series of actions or activities expressed in rupiah figures for a certain period of time. The budget in the Regional Government is commonly referred to as the Regional Revenue and Expenditure Budget (APBD). All regional government revenues and expenditures in the form of money, goods and / services in the current fiscal year must be budgeted in the APBD (Kawedar et al, 2008) [1]. APBD is a unit consisting of regional revenue, regional expenditure and regional financing (Darise, 2008) [2].

In managing local government finances, it must be able to apply the principle of regional independence by optimizing revenue from the Regional Original Revenue (PAD) sector. Original Regional Revenue is a source of Regional Government revenue originating from the region itself based on its capabilities. Original Regional Revenue consists of local taxes, regional levies, the results of separated regional wealth management, and other legitimate regional original revenues (Kawedar, 2008). Local taxes and levies are the two largest sources of PAD. Each region has a different tax base depending on the policy of the local Regional Government. For regions with adequate economic conditions, substantial taxes can be obtained. But for disadvantaged areas, Local governments can only collect a limited amount of taxes. Likewise, the local user fees are different for each region. The ability of the regions to provide funding originating from the regions is highly dependent on the ability to realize this economic potential into forms of economic activity that can create revolving funds for sustainable regional development (Darwanto and Yustikasari, 2007) [3].

Local government must be able to allocate capital expenditure budget properly because capital expenditure is one of the steps for local governments to provide services to the public. Capital expenditure is related to long-term financial planning. Saragih (2003) states that the use of spending should be allocated for productive things such as for carrying out development 
activities[4]. Adequate facilities and infrastructure to help people carry out daily activities safely and comfortably which will affect the level of community productivity. Increasing Capital Expenditures in the form of fixed assets such as infrastructure development and infrastructure for the public interest is very important to improve the economy because the higher the capital expenditure the higher the economic productivity. To be able to increase the allocation of capital expenditures, it is necessary to know the variables that affect the allocation of capital expenditures, such as local taxes, local levies, and profit sharing funds. The most dominant government revenue is taxes, the tax contribution to the government budget is very large, so that the role of taxes is so central. For this reason, the government always tries to increase revenue from the tax sector, through efforts to eradicate the tax mafia. The government is currently improving its tax system because the old system is considered to have many weaknesses. This is done to secure state revenue from the tax sector from being leaked, this effort is made so that state revenue from taxes from the years continues to increase. Local governments are expected to be better able to explore financial sources, especially to meet the needs of government financing and development in the region through Regional Original Income (PAD). The demand for an increase in Regional Original Revenue (PAD) is getting bigger along with the increasing number of central government authorities being delegated to the regions.

In order to improve the welfare of the people, the government of North Sulawesi is trying to increase local revenue, one of which is through local taxes and levies. There is a close relationship between regional revenue, economic development and community welfare. When the higher the regional revenue, the higher the opportunity to build the regional economy and prosper the society.

The potentials in North Sulawesi should be maximized again to increase the source of revenue received by the regions. The aim of increasing local taxes and levies is to boost the economy of North Sulawesi by building infrastructure that supports the economy. With this development, it is hoped that the economy can develop and the ultimate goal is the welfare of the community.

Considering that local taxes and levies are very potential regional revenues, the local government in this case the Dispenda should be able to optimize these levies without neglecting the principle of justice. By sticking to the principle of justice in establishing policies regarding local levies, it is hoped that the community as tax and retribution payers will not feel burdened.

Delegation of authority from the Central Government to Regional Governments accompanied by transfers of funds, facilities and infrastructure as well as human resources. The transfer of funds from the Central Government to Regional Governments is manifested in the form of balancing funds, one of which is the Revenue Sharing Fund (DBH). Funds from the Central Government are used by Regional Governments effectively and efficiently to improve services to the public (can be used to increase capital expenditures). The implementation of regional autonomy can not only be seen from how much the regions will receive balanced funds, but this must be balanced with the extent to which regional financial management instruments or systems are able to provide nuances of financial management that are more just, rational, transparent, participatory and responsible.

Several studies on local taxes, local levies and profit sharing funds on capital expenditures have been carried out and there are different results among these are the results of research by Handayani et al. (2015) found that local taxes and levies have no effect on regional spending [5]. The research results of Sudika and Budiartha (2017) also found that local retribution has no effect on capital expenditure [6]. Rahmawati and Tjahjono (2018) also produce that fees have no effect on capital expenditure [7]. However, the results of research by Sudika and Budiartha (2017) found that local taxes have an effect on capital spending [6]. Rahmawati and Tjahjono (2018) found that local taxes have an effect on capital spending [7]. Wandira (2013) found that profit sharing funds have no effect on capital spending [8]. Likewise, the results of Rasyid (2018) who found that profit sharing funds have no effect on capital expenditure [9]. However, the research results of Handayani et al. (2015) found that revenue sharing has an effect on regional spending [5]. The difference in the results of the study made the researchers conduct this research.

\section{LITERATURE REVIEW}

\subsection{Capital Expenditures}

According to Mardiasmo (2011: 187), "Capital expenditure is a group of direct expenditures used to finance investment activities (adding assets)" [10]. Capital Expenditures are budget expenditures that are part of the classification of regional expenditures, namely groups of regional expenditures according to programs and activities included in the direct expenditure group where capital expenditures are used to finance investment activities or add assets carried out by the government. Furthermore, Erlina and Rasdianto (2013) define capital expenditures as budget expenditures for tangible fixed assets that provide benefits for more than one accounting period [11].

Capital expenditure according to Government Regulation No. 71/2010 concerning Government Accounting Standards (SAP), discloses that capital expenditures are "budget expenditures for the acquisition of fixed sets and other assets that provide benefits for more than one accounting period. Capital expenditures include, among others, capital expenditures for the acquisition of land, buildings and buildings, equipment, intangible assets. "

Based on some of the above definitions, it can be concluded that capital expenditure is budgetary expenditure which is part of the classification of regional expenditure according to programs and activities included in the direct expenditure group, where capital expenditure is used in the context of capital formation which is to acquire or increase fixed assets or inventory that 
provides benefits. More than twelve months (one accounting period), including expenses for maintenance costs that are to maintain or increase the useful life, increase the capacity and quality of assets.

\subsection{Local tax}

In the book of Law of the Republic of Indonesia Number 28 of 2009 concerning Regional Taxes and Regional Retributions, the definition of regional taxes is: Taxes are mandatory contributions to regions that are owed by an individual or entity that is compelling under the Law, with no direct compensation. and used for regional needs for the greatest prosperity of the people. Furthermore, Siahaan (2013: 17) defines as follows: Regional Tax, hereinafter referred to as Tax, is a mandatory contribution to the Region that is owed by an individual or entity that is compelling based on law, without receiving direct compensation and is used for regional needs for the amount of -the amount of prosperity of the people[12].

\subsection{Regional Retribution}

Definition retributionRegions according to Mardiasmo (2011: 14) are: Regional Retribution, hereinafter referred to as retribution, is a regional levy as payment for services or the granting of certain permits specifically provided and / or given by local governments for the benefit of individuals or entities [10]. A regional levy is a levy that provides / is given by the regional government for the interests and benefits of the region and can be enjoyed by individuals / entities. Retribution as a component of Regional Original Revenue has good prospects for development, which must be managed professionally and transparently in the context of optimization and efforts to increase contributions to the Regional Budget (APBD) through intensification of collection and extensification of subjects and objects of regional levies.

\subsection{Profit Sharing Fund}

According to Noordiawan (2007: 78) Profit Sharing Funds (DBH) are funds sourced from APBN revenues allocated to regions by taking into account the potential of producing regions based on certain percentage figures to fund regional needs in the context of implementing decentralization [13].

Profit Sharing Funds are provided by the Central Government to overcome the problem of vertical fiscal balance, namely to ensure a balance between fiscal needs and fiscal sources at various levels of government (Solihin, 2011). The use of DBH is the same as DAU. Both funds are "block grants", meaning that if these funds have been received by the Regional Government in the Regional Treasury, these funds can be allocated to various regional expenditures as needed so that DBH can become one of the sources of funds to finance capital expenditures.

Tax Profit Sharing Fund itself consists of Land and Building Tax (PBB), Fees for Acquisition of Land and Building Rights (BPHTB), and Income Tax (PPh), both from Domestic Individual Taxpayers and from PPh 21 (Noordiawan, 2007: 92 ) [13].

\subsection{Hypothesis}

The hypothesis in this study is formulated as follows:

H1: Local taxes, local levies, and profit-sharing funds affect capital expenditures.

H2: Local taxes have an effect on capital spending.

H3: Regional levies have an effect on capital spending.

H4: Profit-sharing funds have an effect on capital spending. 


\section{RESEARCH METHOD}

\subsection{Operational Definition of Research Variables}

a. Capital Expenditures

Capital expenditures are budget expenditures made in the context of capital formation which are of the nature of obtaining or adding to fixed assets / inventory which provide benefits for more than twelve months (one accounting period), including expenses for maintenance costs that maintain or increase the useful life increase the capacity and quality of assets. Capital expenditure is formulated as follows:

Capital Expenditure $=$ Shopping for Land + Shopping for Equipment and Machinery + Shopping for Buildings and Buildings + Shopping for Roads, Irrigation and Networks + Shopping for Other Assets

b. Local tax

Regional Tax is the amount of tax paid by compelling taxpayers who do not get direct compensation and the proceeds are used to finance regional expenditures in order to carry out development, regional administration and for community services, which is measured in rupiah.

c. Regional levies

Levies are local levies on services or the granting of certain permits specifically provided and given by local governments for the benefit of individuals or entities, which are measured in rupiah.

d. Profit sharing fund

Profit sharing funds are funds originating from APBN revenues which are used to finance regional needs in the context of implementing decentralization, measured in rupiah.

\subsection{Population and Sampling Techniques}

The population of this research is all regencies / cities within the scope of North Sulawesi province are 15 districts / cities, consisting of 11 regencies and 4 cities. The sampling method used in this study used purposive sampling with data criteria regarding local taxes, local levies, profit sharing funds and complete capital expenditures from 2015 to 2017 , thus obtaining a sample of 10 districts / cities. in North Sulawesi Province.

\subsection{Data analysis technique}

The method of analyzing the data in this research was carried out using Multiple Linear Regression analysis, which was used to determine the effect of local taxes, levies, and profit sharing on capital expenditures, using multiple linear regression with the help of the SPSS program with the equation:

$$
\begin{aligned}
& \mathrm{Y}=\mathrm{a}+\mathrm{b} 1 \mathrm{X} 1+\mathrm{b} 2 \mathrm{X} 2+\mathrm{b} 3 \mathrm{X} 3+\mathrm{e} \\
& \text { Information }: \\
& \mathrm{Y} \quad=\text { Capital expenditure } \\
& \mathrm{a} \quad=\text { constant number } \\
& \mathrm{b} 1 . . \mathrm{b} 3=\text { regression coefficient } \\
& \mathrm{X} 1 \quad=\text { Local taxes } \\
& \mathrm{X} 2 \quad=\text { Regional levies } \\
& \mathrm{X} 3 \quad=\text { Profit sharing } \\
& \mathrm{e} \quad=\text { Error term }
\end{aligned}
$$


International Journal of Advances in Scientific Research and Engineering (ijasre), Vol 6 (12), December -2020

\section{RESULTS AND DISCUSSION}

\subsection{Multiple Regression Analysis}

Multiple regression analysis is used to determine the influence of local taxes, local levies and profit sharing funds against capital expenditure (Y). The results of these calculations can be seen in the table below:

Table 1. Recapitulation of the Results of Multiple Linear Regression Analysis

\begin{tabular}{|c|c|c|c|c|c|}
\hline Variable & \multicolumn{2}{|c|}{ Information } & $\begin{array}{l}\text { Regression } \\
\text { Coefficient }\end{array}$ & $t_{\text {count }}$ & Sig. \\
\hline $\mathrm{X} 1$ & \multicolumn{2}{|l|}{ Local tax } & 0.657 & 2,824 & 0.009 \\
\hline $\mathrm{X} 2$ & \multicolumn{2}{|l|}{ Regional levies } & 0.363 & 0.500 & 0.621 \\
\hline X3 & \multicolumn{2}{|l|}{ Profit sharing fund } & 1,063 & 0.889 & 0.382 \\
\hline \multicolumn{2}{|l|}{ Constant } & \multicolumn{4}{|l|}{151088298051} \\
\hline \multicolumn{2}{|l|}{$\mathrm{R}$} & 0.764 & & & \\
\hline \multicolumn{2}{|l|}{ Adjusted $R$ Square } & 0.535 & & & \\
\hline \multicolumn{2}{|l|}{ Fcount } & 12,118 & & & \\
\hline \multicolumn{2}{|l|}{ Sig. F } & 0,000 & & & \\
\hline \multicolumn{2}{|l|}{$\mathrm{n}$} & 30 & & & \\
\hline \multicolumn{6}{|c|}{ The dependent variable $=$ capital expenditure $(Y)$} \\
\hline \multicolumn{6}{|l|}{$\mathrm{t}$ table $=2,056$} \\
\hline \multicolumn{6}{|l|}{ Ftable $=1.99$} \\
\hline
\end{tabular}

The results of the multiple regression calculations can be seen in the following formulations:

$\mathrm{Y}=\mathrm{a}+\mathrm{b} 1 \mathrm{X} 1+\mathrm{b} 2 \mathrm{X} 2+\mathrm{b} 3 \mathrm{X} 3$

$\mathrm{Y}=151088298051+0.657 \mathrm{X} 1+0.363 \mathrm{X} 2+1.063 \mathrm{X} 3$

Based on the results of this equation, it can be explained as follows:

a. The regression coefficient X1 (local tax) is 0.657 (b1), indicating the magnitude of the influence of X1 (local tax) on capital expenditure (Y), the regression coefficient is positive, indicating X2 (local tax) has a unidirectional effect on capital expenditure (Y), which means that each an increase in local tax variables has a tendency to increase capital spending, and vice versa.

b. The regression coefficient X2 (regional levies) is 0.363 (b2), indicating the magnitude of the influence of X2 (regional levies) on capital expenditures (Y), the regression coefficient is positive, indicating X2 (regional levies) has a direct effect on capital expenditure (Y) an increase in the regional levy variable has a tendency to increase capital spending, and vice versa.

c. The regression coefficient X3 (profit sharing) is 1.063 (b3), indicating the magnitude of the influence of X3 (profit sharing) on capital expenditure, the regression coefficient is positive, indicating X3 (profit sharing) has the opposite effect on capital expenditure $(\mathrm{Y})$, which means the higher the profit-sharing fund, the lower the capital expenditure, and vice versa.

Multiple correlation coefficient $(\mathrm{R})$ of 0.764 ; shows that collectively there is a strong and unidirectional relationship between local taxes, local levies, and revenue sharing, with capital expenditure (Y) of $76.4 \%$. This relationship can be categorized as strong, as it is known that a relationship is said to be perfect if the correlation coefficient reaches $100 \%$ or 1 (either with positive or negative numbers).

From the results of the multiple linear regression analysis above, it can be seen the coefficient of determination (adjusted $R$ square) of 0.535. This figure shows that the variables of local taxes, levies, and profit sharing funds are able to contribute to capital expenditure by $53.5 \%$, while the remaining $46.5 \%$ is caused by other variables outside the research variables. 


\subsection{Testing Hypothesis}

a. Hypothesis Testing 1

To test the first hypothesis which states that local taxes, local levies and profit sharing have an effect on capital expenditure, using the $\mathrm{F}$ test is used to test whether all The independent variables, namely local taxes, local levies, and profit sharing funds together have a significant effect on capital expenditures, by comparing Fcount with Ftable.

From the calculation results obtained the value of Fcount of 12,118, while Ftable on $\alpha=5 \%$ of 1.99 ; this means that Fcount $>$ Ftable $(12,118>1.99)$ while the probability value is smaller than $\alpha=0.05(0.000<0.05)$, then Ho is rejected and Ha is accepted, which means that the independent variables: local taxes, local levies, and revenue sharing simultaneously or together have a significant effect on capital spending. Thus the first hypothesis is statistically accepted or tested.

b. Hypothesis Testing 2

To test the second hypothesis which states that Regional taxes have an effect on capital expenditures using the $t$ test. The results of the $t$ test for local taxes show that the value of tcount $=2.824$ while the value of ttable $=2.056$ so that tcount $>$ ttable or a significance value of $0.009<0.05$ so Ho is rejected or Ha is accepted, so that the variable X1 (regional tax) has a significant effect on capital expenditure (Y). Thus both are statistically tested or accepted.

c. Hypothesis Testing 3

To test the third hypothesis which states that regional retribution affect capital expenditures using the t test. The results of the $\mathrm{t}$-test for regional levies obtained the value of $\mathrm{t}=0.500$ while the value of $\mathrm{t}$ table $=2.056$ so that tcount $<$ ttable or a significance value of $0.621>0.05$, so Ho was accepted or Ha was rejected, so the variable X2 (regional retribution) had no effect on capital expenditure (Y). Thus all three statistically neither tested nor rejected.

d. Hypothesis Testing 4

To test the fourth hypothesis which states that profit sharing fund has an effect on capital expenditure by using the $t$ test. The results of the $\mathrm{t}$ test for the profit sharing obtained the value of $\mathrm{t}$ count $=0.889$ while the value of $\mathrm{t}$ table $=2.056$ so that $\mathrm{t}$ count $<\mathrm{t}$ table or a significance value of $0.382>0.05$ so Ho is accepted or Ha is rejected, so the variable X3 (profit sharing) has no effect on capital spending. Thus all four are statistically untested or rejected.

\subsection{Discussion of Research Results}

\section{a. The Influence of Local Taxes on Capital Expenditures}

Based on the results of the analysis, it shows that local taxes have a significant effect on capital spending. The higher the local taxes that districts / cities in North Sulawesi Province receive, the higher the amount of capital expenditures for carrying out government activities and regional development programs. This shows that one of the factors affecting capital expenditure is financial factors that come from local taxes. Local taxes are one of the original regional income sources that come from the potential of each region which must always be increased in order to finance the implementation and expenditure of the regional government, even though each region has different capabilities or potential sources of income.

Local taxes are used as well as possible for regional needs in terms of meeting regional needs. District / city governments in North Sulawesi province can allocate Local Taxes as an important source for allocating capital expenditures. Based on the results of this study, the greater the Regional Taxes obtained or received by a region and the correct utilization of Regional Taxes, the greater the amount of funds used or channeled by the regional government to make capital expenditures. The results of this study support Sudika and Budiartha (2017) [6] and Rahmawati and Tjahjono (2018) [7] which state that local taxes have a significant effect on capital spending. However, the results of this study are not in line with Handayani et al. (2015) [5] and which states that local taxes have no effect on capital spending.

\section{b. The Influence of Local Levies on Capital Expenditures}

Regional levies have no effect on capital expenditure, which means that the level of regional levies has no impact on regional spending. There is no effect of user fees on working capital, because there is an assumption that emphasizes and makes it clear that the community views user fees as part of the program not as regional income and is willing to pay only if the service level is maintained and improved. This research proves that not all regional spending in districts / cities in North Sulawesi Province has been used for the fulfillment of public welfare, because the management of regional expenditures, especially the increase in regional retribution, does not cause an increase in capital spending.

Regional Levies are one of the original sources of regional income, where Regional Levies are collected based on the regulations of each region in accordance with the applicable laws and regulations. The regional government is expected to further optimize the economic potential in the region, including optimizing the results of regional levies so that it can have a 
good impact on capital expenditure. The results of this study are consistent withHandayani et al (2015) [5], Sudika and Budiartha (2017) [6] and Rahmawati and Tjahjono (2018) [7] which states that local charges have no effect on capital spending.

\section{c. The Influence of Profit Sharing Funds on Capital Expenditures}

Profit sharing funds have no effect on capital expenditure. This shows that the level of profit sharing funds does not affect capital spending. This indicates that local governments do not have a large dependence on the central government in financing regional expenditures and expenditures. However, in the long term, this kind of dependence should be getting smaller. Various investments made by local governments are expected to produce positive results, so that local governments can be more independent in utilizing the potential and resources in their regions to be able to meet capital expenditures and not depend on the central government in financing local government expenditures and expenditures. The results of this study are supportive Rasyid (2018) which states that profit sharing has an effect on capital expenditure. However, the results of this study do not support Wandira (2013). [8], Handayani et al. (2015) [5] which states that profit sharing has an effect on capital expenditure.

\section{CONCLUSIONS AND SUGGESTIONS}

\subsection{Conclusion}

a. Local taxes, local levies and profit sharing funds simultaneously affect capital expenditures, which means that the higher local tax revenues, supported by high local fees and profit sharing funds can increase capital spending.

b. Local taxes have an effect on capital expenditures in districts / cities of North Sulawesi Province, which means that high regional taxes are a consideration for local governments in using the revenues earned so that they have an impact on increasing capital spending in districts / cities of North Sulawesi Province.

c. Regional levies do not have a significant effect on capital expenditure in districts / municipalities of North Sulawesi Province, which means that the high and low levels of regional fees do not have an impact on the level of capital expenditure in the districts / cities of North Sulawesi Province.

d. Profit sharing funds have no effect on capital expenditures, which means that the high and low profit sharing funds does not have an impact on the level of capital expenditure in districts / cities of North Sulawesi Province.

\subsection{Suggestions}

Based on the descriptions in the previous chapters and the conclusions above, some suggestions put forward by the author in writing this thesis are as follows:

a. For local governments, it is better if local governments optimize revenues from extracting natural resources such as mining, plantations and waters as well as the potential they have that can contribute to increasing local taxes and levies so that the allocation of capital expenditure can increase which is used for regional development.

b. We recommend that capital spending should be more focused on supporting sectors such as traders and tourism so as to encourage sustainable economic improvement and community independence.

c. For future researchers to see consistency of results research from period to period and to find out more strongly the truth of the results of this research, it is better if research that will be carried out in the future should use other areas in a wider observation period so that differences and similarities that may occur can be seen as well as to add insight and more complete conclusions.

\section{REFERENCES}

1. Kawedar, Warsito, dkk. 2008. Akuntansi Sektor Publik (Pendekatan Penganggaran Daerah dan Akuntansi Keuangan Daerah. Buku 1. Semarang: Salemba Empat.

2. Darise, Nurlan. 2008. Pengelolaan Keuangan Daerah. Jakarta : Indeks Kelompok Media.

3. Darwanto dan Yulia Yustikasari, 2007. Pengaruh Pertumbuhan Ekonomi Pendapatan Asli Daerah dan Dana Alokasi Umum terhadap Pengalokasian Anggaran Belanja Modal, Simposium Nasional Akuntansi X. Makasar.

4. Saragih, Juli Panglima. 2003. Desentralisasi Fiskal dan Keuangan Daerah dalam Otonomi. Bogor: Penerbit Ghalia Indonesia. 
5. Handayani, Sri Putri, Sykry Abdullah dan Heru Fahlevi. 2015. Pengaruh Penerimaan Pajak Daerah, Retribusi Daerah Dan Dana Bagi Hasil (DBH) Terhadap Belanja Modaldi Kabupaten/Kota Di Provinsi Aceh. Jurnal Magister Akuntansi. Pascasarjana Universitas Syiah Kuala. Vol. 4 No. 2: 45 - 50.

6. Sudika, I Komang dan I Ketut Budiartha. 2017. Pengaruh Pajak Daerah, Retribusi Daerah, Dana Alokasi Umum, Dan Dana Alokasi Khusus Pada Belanja Modal Provinsi Bali. E-Jurnal Akuntansi Universitas Udayana. Vol. 21. No. 2: 1689-1718.

7. Rahmawati, Riska dan Achmad Tjahjono. 2018. Pengaruh Pajak Daerah, Retribusi Daerah, Dana Alokasi Umum dan Dana Alokasi Khusus terhadap Belanja Modal di D.I Yogyakarta Tahun 2012-2016. Jurnal Kajian Bisnis. Vol. 26 No. 2 : $195-209$.

8. Wandira, 2013. Pengaruh PAD, DAU, DAK, dan DBH Terhadap Pengalokasian Belanja Modal. Accounting Analysis Journal. Vol. 2 No.1: 45-61.

9. Rasyid, Moh. 2018. Pengaruh Dana Alokasi Umum, Dana Alokasi Khusus, Dana Bagi Hasil Dan Pendapatan Asli Daerah Terhadap Belanja Daerah Kabupaten/Kota Provinsi Sulawesi Tengah. e Jurnal Katalogis. Volume 6 Nomor 1: $204-216$.

10. Mardiasmo. 2011. Perpajakan. Edisi Revisi. Yogyakarta: Andi Offset.

11. Erlina dan Rasdianto 2013. Akuntansi Keuangan Daerah Berbasis Akrual. Penerbit. Brama Ardian.

12. Siahaan, Marihot Pahala. 2013. Pajak Daerah dan Retribusi Daerah Berdasarkan Undang-Undang Nomor 28 Tahun 2009 tentang Pajak Daerah dan Retribusi Daerah. Rajawali Pers : Jakarta.

13. Noordiawan, Deddi. 2007. Akuntansi Pemerintahan. Salemba Empat, Jakarta. 